\title{
Effect of Additional Albumin Administration During Exchange Transfusion on Plasma Albumin-binding Capacity
}

\author{
BEN WOOD, ANN COMLEY, and JANET SHERWELL \\ From the Birmingham Maternity Hospital, Queen Elizabeth Medical Centre, Birmingham 15
}

\begin{abstract}
Wood, Ben, Comley, Ann, and Sherwell, Janet (1970). Archives of Disease in Childhood, 45, 59. Effect of additional albumin administration during exchange transfusion on plasma albumin and reserve albumin-binding capacity. A total of 33 infants undergoing exchange transfusion for hyperbilirubinaemia was divided into two albumin-treated groups and a control group. Both albumin-treated groups showed significantly higher levels of plasma albumin and of reserve albumin-binding capacity in the phase of bilirubin rebound 8 hours or more after exchange. It was not possible to state which method of albumin administration was the more efficient. Up to two-thirds of administered albumin probably diffuses into the extravascular space of newborn infants within 2-3 hours.
\end{abstract}

During the course of a study on bilirubin removal after albumin administration in exchange transfusion (Comley and Wood, 1968) the 2-(4'-hydroxybenzeneazo) benzoic acid dye method of estimating reserve binding capacity was described by Porter and Waters (1966). This method was applied in the evaluation of albumin-enriched transfusions for hyperbilirubinaemia of the newborn.

\section{Material and Methods}

Infants requiring exchange transfusions for hyperbilirubinaemia were treated in three different ways by random selection.

Group 1: 10 infants who were treated by simple two-blood-volume exchange transfusion with acid citrate dextrose (ACD) blood, from which half the supernatant plasma was removed after standing but not centrifuging.

Group 2: 11 infants who at every $100 \mathrm{ml}$. interval had $10 \mathrm{ml}$. $(2.5 \mathrm{~g}$.$) salt-poor human albumin substi-$ tuted for $10 \mathrm{ml}$. blood. In this group all the supernatant plasma was removed from the donor blood after standing, to compensate for the dilution effect of the albumin.

Group 3: 12 infants whose exchange transfusion was preceded by intravenous injection of 1 to $2 \mathrm{~g} . / \mathrm{kg}$. of human albumin 2 to 3 hours before the exchange,

Received 11 June 1969. which was then carried out with half-concentrated blood as in group 1 . Immediately after the exchange a further boost of 0.5 to $1.0 \mathrm{~g} . / \mathrm{kg}$. of albumin was given to cover the post-exchange (rebound) period.

Table I shows that the severity of the haemolytic disease as judged by antibody titre, optical density of amniotic fluid, cord haemoglobin, and age at exchange transfusion (ET) was comparable in all three groups.

TABLE I

Comparative Data in Three Groups

\begin{tabular}{|c|c|c|c|c|}
\hline \multicolumn{2}{|l|}{ Data } & Group 1 & Group 2 & Group 3 \\
\hline $\begin{array}{l}\text { Highest anti- } \\
\text { body titre } \\
(1=\text { low to } \\
6=\text { very } \\
\text { high) }\end{array}$ & Mean & $4 \cdot 8$ & $5 \cdot 1$ & $4 \cdot 9$ \\
\hline $\begin{array}{l}\text { Highest optical } \\
\text { density of } \\
\text { amniotic fluid } \\
\text { ( } 1=\text { low to } \\
5=\text { very } \\
\text { high) }\end{array}$ & Mean & $3 \cdot 0$ & $3 \cdot 1$ & $2 \cdot 3$ \\
\hline Cord Hb (\%) & $\begin{array}{l}\text { Mean } \\
\text { Range }\end{array}$ & $\begin{array}{c}84 \cdot 0 \\
(40-111)\end{array}$ & $\begin{array}{c}83 \cdot 0 \\
(63-107)\end{array}$ & $\begin{array}{c}78 \cdot 8 \\
(35-132)\end{array}$ \\
\hline Age at ET (hr.) & Mean & $\begin{array}{c}49 \cdot 0 \\
(11-81)\end{array}$ & $\begin{array}{c}46 \cdot 0 \\
(14-82)\end{array}$ & $\begin{array}{c}45 \cdot 5 \\
(26-77)\end{array}$ \\
\hline Gestation (wk.) & Mean & $36 \cdot 2$ & $36 \cdot 5$ & $36 \cdot 9$ \\
\hline $\begin{array}{l}\text { Birthweight } \\
\text { (kg.) }\end{array}$ & $\begin{array}{l}\text { Range } \\
\text { Mean } \\
\text { Range }\end{array}$ & $\begin{array}{c}(33-39) \\
2 \cdot 87 \\
(2 \cdot 01-3 \cdot 65)\end{array}$ & $\begin{array}{c}(33-39) \\
2 \cdot 82 \\
(2 \cdot 02-3 \cdot 55)\end{array}$ & $\begin{array}{c}(34-39) \\
2 \cdot 89 \\
(2 \cdot 28-4 \cdot 12)\end{array}$ \\
\hline
\end{tabular}


The rebound bilirubin levels to be mentioned later suggest some differences in severity which are to be discussed. The infants had similar gestational ages and birthweights.

Methods of exchange, sampling, and biochemical methods were as described previously (Comley and Wood, 1968). The reserve albumin-binding capacity (RABC) was estimated by an adaptation of the method of Porter and Waters (1966). RABC was expressed in grammes of albumin reserve per $100 \mathrm{ml}$. of plasma; and also as a percentage of the binding capacity for an albumin standard of approximately $3.8 \mathrm{~g} . / 100 \mathrm{ml}$., which allows comparison with the figures of Porter and Waters. Normal infants had cord blood RABC of $2 \cdot 8-3 \cdot 6 \mathrm{~g}$. per $100 \mathrm{ml}$, with a mean of $3 \cdot 2 \mathrm{~g}$. per $100 \mathrm{ml}$. (SD $0 \cdot 2)$.

\section{Results}

Comparison of plasma levels of albumin and RABC before and immediately after treatment showed as expected that the two albumin-treated groups (Groups 2 and 3) had much higher levels than the Group 1 cases. The more important question was whether these levels were sustained in the next few hours to provide protection against the rising tide of bilirubin that inevitably follows exchange transfusion. It is in this rebound phase (Brown, Zuelzer, and Robinson, 1957) that the residual or 'stable' pool of bilirubin, most of which is in the cells (Sproul and Smith, 1964), slowly equilibrates with the plasma. Continuing haemolysis may add to the accumulation of bilirubin in the plasma to produce levels that require further bilirubin drainage.

In this study therefore the effects of the three different methods of treatment were gauged by comparing pre-exchange plasma levels with those found in the rebound phase, specimens being taken as the bilirubin approached dangerous levels. Table II shows that these specimens were taken at about the same time intervals after exchange in the three groups. The delay in sampling of 8 or more hours (8-46) after treatment had the added advantage that the short-term effects of exchange transfusion or albumin administration on haematocrit and blood volume were likely to have disappeared.

The over-all results are shown in Table II and the effects on bilirubin, albumin, and RABC levels are described individually.

Plasma bilirubin. From a similar starting level the groups behaved slightly differently (see Fig. 1). Taking Group 1 as controls, bilirubin levels in Group 2 rebounded to a slightly higher level, while those in Group 3 rebounded significantly less. The simplest explanation of this is that Group 3 infants were less severely affected than
TABLE II

Over-all Results

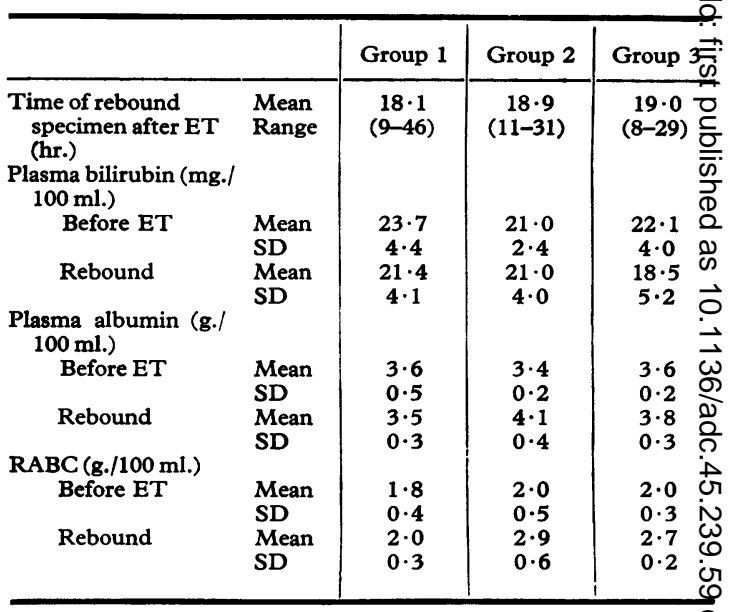

the other two, with smaller accumulation of bili? rubin after the ET. This is discussed later.

Plasma albumin. Fig. 2 shows that all three groups had comparable pre-exchange levels ang the simple exchange (Group 1) cases had a slight fall in the rebound phase, as would be expeges from the use of ACD blood. Group 2 with ghe larger amount of albumin administered had a highly significantly higher level $(p<0.001)$, w Group 3 had a smaller but highly significar increase $(p<0.01)$ over the pre-exchange level.

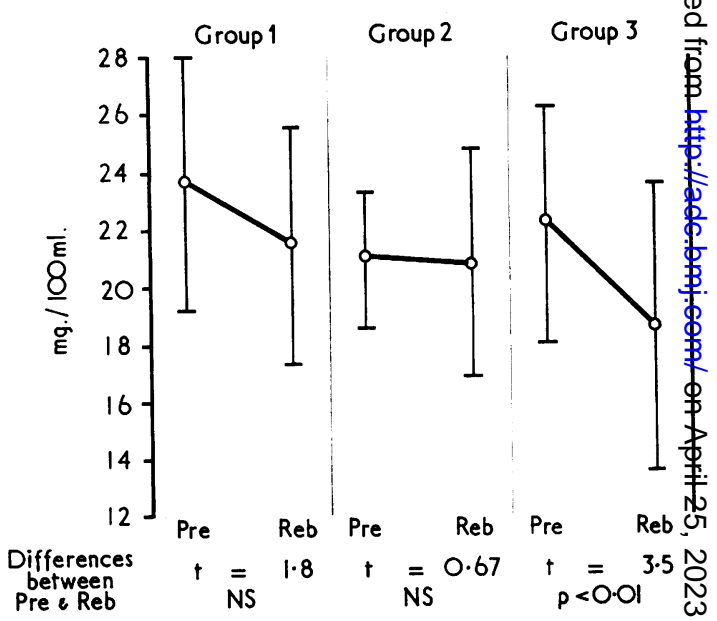

FIG. 1.-Pre-exchange plasma bilirubin levels compare with those found in the rebound phase in the three groups Mean and 1 SD showing significantly lower rebour level in Group 3. (Pre = specimen taken before exchang? Reb $=$ specimen taken in rebound phase.) 


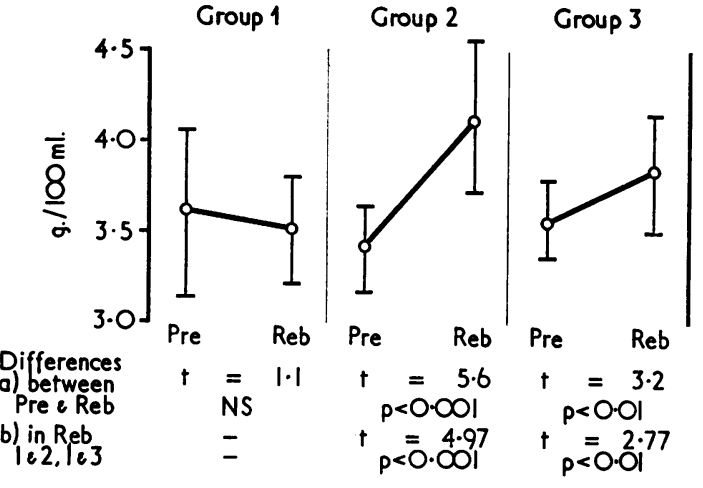

FIG. 2.-Pre-exchange plasma albumin levels compared with those found in the rebound phase in the three groups. Significantly higher levels are shown in the albumintreated groups, (a) when the rebound level is compared with the pre-exchange one in the same group, and (b) when the rise in plasma albumin in each albumin-treated group is compared with the rise in the simple exchange group (by the method of paired differences).

Reserve albumin-binding capacity. In Fig. 3, Group 1 cases exchanged with bilirubin-free ACD blood showed little or no improvement in their bilirubin-binding capacity in the rebound specimen. Presumably the bilirubin diffusion from the tissues had taken up practically all the newly-provided binding sites in the donor blood. Thus, though an average of 18 hours had been gained the situation was much the same as prevailed before the exchange.

After much the same time interval the two albumin-treated groups showed a significant increase in binding capacity, suggesting the presence of a valuable reserve of binding sites to mop up any further bilirubin accumulation.

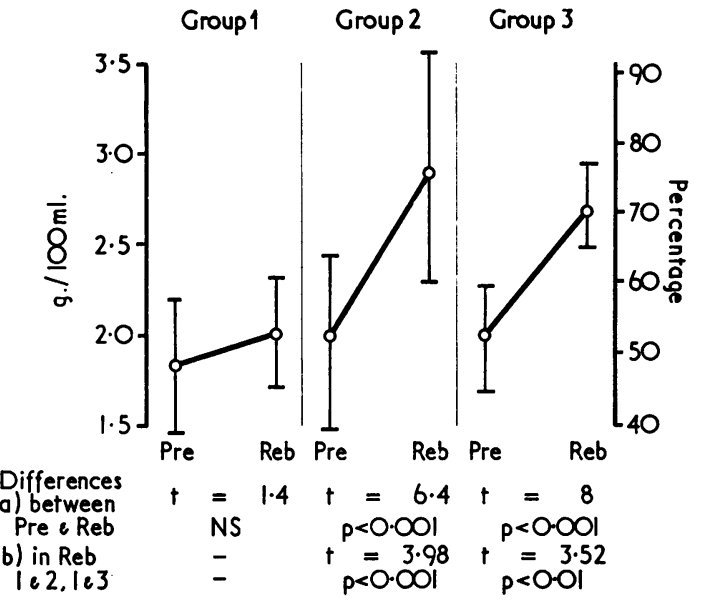

FIG. 3.-Plasma reserve albumin-binding expressed in g. $/ 100 \mathrm{ml}$. in left-hand ordinate and as percentage of $3.8 \mathrm{~g} . / 100 \mathrm{ml}$. albumin standard in right hand ordinate. Significantly higher levels are shown in the albumintreated groups, (a) when the rebound phase is compared with the pre-exchange finding in the same group, and (b) when rise in binding capacity in each group is compared with the rise in the simple exchange cases (by the method of paired differences).

Fate of injected albumin. Table III shows the data on 8 of the Group 3 infants where haematocrit readings were recorded enabling the amount of albumin remaining in the circulation to be calculated. The results depend upon an assumed blood volume of $85 \mathrm{ml} . / \mathrm{kg}$., which may vary as shown by Sproul and Smith (1964) from 62 to $93 \mathrm{ml} . / \mathrm{kg}$. They show a loss of up to two-thirds of the administered albumin from the circulation within the period of 2-3 hours.

\section{TABLE III}

Fate of Injected Albumin

\begin{tabular}{|c|c|c|c|c|c|c|c|c|c|c|c|c|c|c|}
\hline \multirow{2}{*}{$\begin{array}{l}\text { Case } \\
\text { No. }\end{array}$} & \multirow{2}{*}{$\begin{array}{l}\text { Wt. } \\
\text { (kg.) }\end{array}$} & \multirow{2}{*}{$\begin{array}{l}\text { Blood } \\
\text { Volume } \\
\text { (ml.) }\end{array}$} & \multicolumn{4}{|c|}{ Before Albumin } & \multicolumn{2}{|c|}{ Dose of Albumin } & \multicolumn{4}{|c|}{ 2-3 Hours After Albumin } & \multicolumn{2}{|c|}{$\begin{array}{c}\text { Albumin Retained } \\
\text { in Circulation }\end{array}$} \\
\hline & & & $\begin{array}{c}\mathrm{PCV}_{1} \\
(\%)\end{array}$ & $\begin{array}{l}\mathrm{PV}_{\mathbf{3}} \\
(\mathrm{ml} .)\end{array}$ & $\begin{array}{c}\mathbf{P A}_{1} \\
(\mathrm{~g} \cdot / 100 \\
\mathrm{ml} .)\end{array}$ & $\begin{array}{c}\mathrm{CA}_{1} \\
(\mathrm{~g} .)\end{array}$ & (g.) & (g./kg.) & $\begin{array}{c}\mathrm{PCV}_{2} \\
(\%)\end{array}$ & $\begin{array}{l}\mathbf{P V}_{2} \\
(\mathrm{ml} .)\end{array}$ & $\begin{array}{c}\mathbf{P A}_{2} \\
\text { (g. } / 100 \\
\text { ml. })\end{array}$ & $\begin{array}{r}\mathrm{CA}_{2} \\
(\mathrm{~g} .)\end{array}$ & ${ }^{\star \mathrm{CA}_{22}}$ & $\begin{array}{l}\% \text { of } \\
\text { Dose }\end{array}$ \\
\hline $\begin{array}{l}1 \\
2 \\
3 \\
4 \\
5 \\
6 \\
7 \\
8\end{array}$ & $\begin{array}{l}3 \cdot 00 \\
2 \cdot 70 \\
2 \cdot 85 \\
4 \cdot 12 \\
2 \cdot 63 \\
3 \cdot 11 \\
3 \cdot 16 \\
2 \cdot 28\end{array}$ & $\begin{array}{l}255 \\
230 \\
242 \\
350 \\
224 \\
264 \\
269 \\
194 .\end{array}$ & $\begin{array}{l}39 \\
48 \\
36 \cdot 5 \\
42 \\
39 \\
40 \\
35 \\
38 \cdot 5\end{array}$ & $\begin{array}{l}156 \\
119 \\
154 \\
203 \\
136 \\
159 \\
175 \\
119\end{array}$ & $\begin{array}{l}3 \cdot 5 \\
3 \cdot 3 \\
3 \cdot 3 \\
3 \cdot 6 \\
3 \cdot 8 \\
3 \cdot 4 \\
3 \cdot 4 \\
3 \cdot 5\end{array}$ & $\begin{array}{l}5 \cdot 44 \\
3 \cdot 94 \\
5 \cdot 08 \\
7 \cdot 31 \\
5 \cdot 18 \\
5 \cdot 39 \\
5 \cdot 94 \\
4 \cdot 17\end{array}$ & $\begin{array}{l}7 \cdot 5 \\
5 \cdot 0 \\
6 \cdot 25 \\
6 \cdot 25 \\
3 \cdot 75 \\
2 \cdot 5 \\
6 \cdot 25 \\
4 \cdot 5\end{array}$ & $\begin{array}{l}2 \cdot 50 \\
1 \cdot 85 \\
2 \cdot 19 \\
1 \cdot 52 \\
1 \cdot 43 \\
0 \cdot 80 \\
1 \cdot 98 \\
1 \cdot 97\end{array}$ & $\begin{array}{l}36 \\
38 \cdot 5 \\
30 \\
39 \\
32 \\
36 \cdot 5 \\
31 \\
33\end{array}$ & $\begin{array}{l}163 \\
141 \\
170 \\
214 \\
152 \\
168 \\
185 \\
130\end{array}$ & $\begin{array}{l}4 \cdot 7 \\
4 \cdot 1 \\
3 \cdot 8 \\
4 \cdot 1 \\
4 \cdot 8 \\
3 \cdot 7 \\
4 \cdot 0 \\
4 \cdot 4\end{array}$ & $\begin{array}{l}7 \cdot 67 \\
5 \cdot 79 \\
6 \cdot 44 \\
8 \cdot 76 \\
7 \cdot 30 \\
6 \cdot 21 \\
7 \cdot 41 \\
5 \cdot 71\end{array}$ & $\begin{array}{l}2 \cdot 23 \\
1 \cdot 85 \\
1 \cdot 36 \\
1 \cdot 45 \\
2 \cdot 12 \\
0 \cdot 82 \\
1 \cdot 47 \\
1 \cdot 54\end{array}$ & $\begin{array}{l}30 \\
37 \\
22 \\
23 \\
57 \\
33 \\
24 \\
34\end{array}$ \\
\hline
\end{tabular}

$\mathbf{P V}=$ plasma volume; $\mathbf{P A}=$ plasma albumin; $\mathbf{C A}=$ circulating albumin.

$\star \mathrm{CA}_{2}-\mathrm{CA}_{1}=$ amount of albumin retained in circulation. 


\section{Discussion}

From a previous study it was shown that human albumin given in conjunction with exchange transfusion increased bilirubin removal, particularly when large amounts of albumin were administered. In the present study both groups of albumintreated infants showed a significant increase of plasma albumin and reserve albumin-binding capacity in the rebound period. In this small number of cases it is not possible to decide which of the two methods is to be preferred. At first sight it seems that Group 3 'prime and boost' method is the more efficient as it achieves practically the same results with less albumin than Group 2 $(2.6 \mathrm{~g}$. instead of $4.5 \mathrm{~g}$. per kg.). As mentioned earlier, however, this may be a false conclusion if the Group 3 babies were less severely affected and therefore liable to a lower bilirubin rebound and smaller take-up of reserve binding capacity. The rebound plasma albumin levels (Fig. 2) would not be affected by this, and here the Group 2 cases have significantly higher levels.

Regarding the fate of the administered albumin, it has been shown by Sterling (1951) that the intravascular fraction of albumin amounts to about half the total exchangeable pool, while Gitlin and Janeway (1953) showed that there is rapid movement of plasma proteins in both directions between the two compartments. Under very similar conditions to ours, G. Th. Panagopoulos and T. Valaes (1969, personal communication) found that about half the amount of albumin given intravenously left the intravascular space within 21 hours. The validity of our findings depends on the circulating red cell mass remaining the same after the albumin injection. If its administration caused an increase of circulating red cells (by contraction of the spleen for instance) as well as its known and measured effect on haematocrit, then the amount of albumin retained in the circulation would be greater than on shown. The large dose of albumin used in our infants may have had such an effect and thus account for the apparently greater shift from the circulation into the extravascular space. The $\stackrel{0}{9}$ retention of albumin within the body may well be of advantage in preventing tissue bilirubin toxicity, until hepatic conjugation increases sufficiently to cope with bilirubin production (Bowen, Porter, and Waters, 1959).

If brain damage can be shown to be prevented in this way new criteria for repeat exchange transfusion will have to be established.

We are grateful for statistical help which was carried $\stackrel{\circ}{\Omega}$ out by Miss D. J. Powell and Dr. J. A. H. Waterhouse, and we are indebted to the Birmingham Children's Hospital Research Fund for a grant.

\section{REFERENCES}

Bowen, W. R., Porter, E., and Waters, W. J. (1959). The protective action of albumin in bilirubin toxicity in newborn puppies. (Abstr.) American fournal of Diseases of Children, 98, 568.

Brown, A. K., Zuelzer, W. W., and Robinson, A. R. (1957). Studies $\frac{D}{O}$ in hyperbilirubinemia II. American fournal of Diseases of Children, 93, 274

Comley, A., and Wood, B. (1968). Albumin adminstration in exchange transfusion for hyperbilirubinemia. Archives of Disease in Childhood, 43, 151.

Gitlin, D., and Janeway, C. A., (1953). The dynamic equilibriug between circulating and extravascular plasma proteins. Science 118, 301.

Porter, E. G., and Waters, W. J. (1966). A rapid micromethod for measuring the reserve albumin binding capacity in serum from newborn infants with hyperbilirubinemia. Fournal of Laboratory and Clinical Medicine, 67, 660.

Sproul, A., and Smith, L. (1964). Bilirubin equilibration during exchange transfusion in hemolytic disease of the newborn. (\$) Fournal of Pediatrics, 65, 12.

Sterling, K. (1951). The turnover rate of serum albumin in man as measured by $\mathrm{I}^{131}$-tagged albumin. Fournal of Clinical Investigation, 30, 1228.

Correspondence to Dr. B. Wood, The Children's Hospital, Birmingham, 16. 